\title{
Learner Autonomy in EFL Studies in Vietnam: A Discussion
}

\section{from Sociocultural Perspective}

\author{
Tin Tan DANG \\ Faculty of Education, La Trobe University \\ E-mail: datati@gmail.com
} This study was funded by La Trobe University Postgraduate Research Scholarship and Endeavour International
Postgraduate Research Scholarship

\begin{abstract}
Learner autonomy has been identified as a complicated capacity that potentially has a great impact on personal growth and achievement. Different mediated attributes associated with situational, psychological, cultural and political aspects of this construct have been developed and examined to facilitate the promotion of this educational goal. Taking this into account, this paper adopts socio-cultural perspective to localize the situation of EFL learning in higher education in Vietnam. Personal reflections and part of the data generated from a large-scale project are extracted to illustrate a dilemma of the context where learner autonomy can be either fostered or hindered deliberately within various community constraints. The paper finishes with a discussion on the implementation of local learner autonomy promoting practices and puts forward some directions for further research.
\end{abstract}

Keywords: Learner autonomy, Socio-culture, Vietnamese EFL undergraduates

\section{Introduction}

Learner autonomy has been claimed to be an ultimate goal of education for a long time (Benson, 2001, 2009; Waterhouse, 1990). Particularly in second language learning, the concept has been argued to be very complex (Little, 2003) and socially driven (Smith \& Ushioda, 2009). Freedom, choice, and negotiation are often identified as crucial environment factors for learner autonomy development (e. g., Lamb, 2009; Raz, 1986; Sinclair, 2009). Meanwhile, in the context of education in Vietnam generally, students are often described to be passive in class and familiar with rote learning. Teachers are used to dictating the class and do not give students enough opportunities to express themselves. Therefore, this study is to explore possible situational constraints that produce conflicts with the prerequisite notional conditions for learner autonomy. It then proposes suggestions for fostering learner autonomy in the local context to achieve part of the national curriculum objectives and meet the labor market requirements.

\section{Conceptualizing Learner Autonomy}

Driven by the concept of freedom and autonomy in philosophy, the Council of Europe's Modern Languages Project initiated the construct of learner autonomy in the early 1980s. It was defined as "the ability to take charge of one's own learning" (Holec, 1981, p. 3), and this becomes the most cited definition in the literature of the field (Benson, 2009). Later, "ability" and "take charge of" have often been replaced by "capacity" and "take responsibility for" respectively. These word substitutions seem to be a matter of linguistics purely, and the semantic aspects of the construct remain unchanged. This ability was further explained not to be "inborn but must be acquired" mostly by formal education practices (Holec, 1981, p. 3). As educational ideology and philosophy have been interpreted differently, depending on particular social and political situations, learner autonomy has also been understood and translated into practice in various ways.

Psychological perspective (Benson, 2006) often considers learner autonomy as a capacity, consisting of two cyclically interrelated elements, namely "behavioral" and "(meta) cognitive" (Horváth, 2005; Rivers, 2001). These two elements allow individuals to initiate, monitor, and regularly evaluate their learning processes (Little, 1990, 2003) with clear objectives and goals set in advance (Purdie, Hattie, \& Douglas, 1996; Schunk \& Zimmerman, 1994). Learner autonomy is also manifested by learners' critical reflections on the course they are involved in and their requests for significant changes (Rivers, 2001).

Technical perspective (Benson, 2006) views learner autonomy as a "situation" where learners are completely responsible for the performance of their learning activities (Dickinson, 1987). It is a resource rich environment that allows one to select what, when and how to learn to achieve their targets (Oxford, 2003; Pennycook, 1997). Most of the studies adopting this perspective have been conducted in self-access learning centers (SLCs), and they have indicated that authentic materials and personalized learning activities can foster learner autonomy (e. 
g., Brandon, 2003; Riley \& Zoppis, 1985). Therefore, these studies have paid significant attention to the preparation and organization of learning activities as well as technical supports and consultation services provided in each learning environment.

Sociocultural perspective (Benson, 2006; Oxford, 2003) construes learner autonomy as a socially-shaped variable (Smith \& Ushioda, 2009) which is constructed during one's negotiation with his/her living environment. Being a member of a community, any individual needs to deal with different matters, people, and relationships on a daily basis; and learner autonomy is acquired during the execution of these processes. This argument acknowledges impacts of both personal and situational attributes to the formation and development of learner autonomy. As a result, research adopting this perspective often provides learners with more contextual choices, dialogic negotiation, interactive activities and critical reflection as autonomy promoting practices (e. g., Little, 2009; Miller, 2009; Sinclair, 2009).

As presented above, the historic development of learner autonomy in language learning has received diversified interpretations (Toohey, 2007), and that should be what to be expected, especially for such a "susceptible" construct (Smith, 2003) to be localized properly. Nevertheless, it has been reported to increase learning engagement (Dam, 1990; Little, 1991; Miller, Hopkins, \& Tsang, 2005), motivation, and knowledge retention (Bachman, 1964; Dickinson, 1987; Ellis, 1994; Gardner \& MacIntyre, 1991; Holec, 1987; Rivers, 2001). Therefore, examining a particular situation socially and culturally to extract the locally-valued attributes of learner autonomy is prerequisite for designing learner autonomy promoting practices.

\section{Facilitating Factors for Learner Autonomy and the Context of Vietnamese EFL Education}

\section{1. Constructing an Analytical Framework}

Provided with different perspectives on learner autonomy, this section attempts to draw a connection among them, linking them altogether to produce a comprehensive framework. Employing Vygotsky's notions of socio-cultural theory (Lantolf, 2000; Lantolf \& Thorne, 2006) and community of practice (Lave \& Wenger, 1991; Wenger, 1999; Wenger, McDermott, \& Snyder, 2002), the section locates learners into a local environment whose identities, resources, and practices shape their learner autonomy (Toohey, 2007). Psychological attributes of learner autonomy are basically generated from one's access to and interaction with the desires and ideologies of the local community. Meanwhile, technical attributes are generally mediated by the local resources. Therefore, the exercise of learner autonomy is internally produced after one's multi-directional negotiations with his/her community enablements and constraints. These are illustrated in Figure 1.

Interactions and negotiations of an individual with his/her community can be one-on-one, immersion or delegations (Wenger, 1999), depending on his/her position in a particular activity. The level of one's engagement in a situation also reflects both his/her personal characteristics, constraints, and enablements created by that contemporary context. In another word, moving one's position from a peripheral member to an insider, from a passive to an active participant, and from a spontaneous to a controlling learner in a community requires a number of facilitative factors and practices from the surroundings. Therefore, learner autonomy is a socially-bound capacity and its development needs to be addressed in relation to other associated variables in the context.

This framework also helps reduce the probability of individualistic perspective on learner autonomy which has been sometimes discussed in the literature (e. g., Pemberton, Toogood, \& Barfield, 2009). On the one hand, the framework acknowledges the importance of personal attributes and independent internalization. On the other hand, it values external contributions from the environment. Therefore, the highest level of learner autonomy should be still described via dialogic negotiations and interactions with the immediate situation. It should not be indicated as an ability to work alone only. Adopting this framework, the following section addresses its three core elements in the studied context.

\section{2. Analyzing the Local Situation}

3. 2. 1. Resources

Most of Vietnamese undergraduate students, majoring in English as a Foreign Language (EFL), often have access to limited material resources at school. In an individual interview within this project, an EFL student in the second semester in a reasonably large university in the south of Vietnam indicated that he did not know if the school/faculty had a computer lab or a similar place for studying purposes. The same response was also given by another student who had been in the EFL program for two years. Students often have to purchase reference books, English magazines, and other materials by themselves because they cannot get them from the school library, or the library materials do not appeal to them.

The opportunity for internet access, out of the class time, of course, is not equal to every student. While it is very easy for many of them who have home computers with broadband connection, it becomes difficult for many others who come from the country and stay in the dormitory. As there is not enough physical space for desktop 
settings in the dormitory rooms and affording a laptop seems infeasible, most of these students end up with either using the internet café services or avoiding using it. A student reported that he went online once or twice a week for around an hour each. Another one said that she did not know what blog or social network was although she knew that many of her friends used it.

\section{2. 2. Practices}

Being strongly considered part of the Eastern culture, the popular philosophy of educational practices in Vietnam is more associated with absorbing and memorizing than experimenting and producing knowledge. Although a lot of investments and efforts (e. g., MOET, 2008; World Bank, 2006) have been made to improve the perspectives of local learners, teachers and stakeholders on learning, classroom practices and students' learning activities have not been identified to change much. Communicative language teaching method and student-centered approach in second language training have not consistently been reported to be effective, given various situational problems such as big-size class, rigorous test-oriented system, and heavy learning workload. Therefore, several teaching practices derived from these "new" methods have not been widely accepted or appropriately implemented.

In addition, with the adoption of the centralized mechanism, the national education system prescribes almost all of school operation practices. Both managerial and academic activities such as student recruitment processes, training contents, and testing schemes are monitored. Traditionally, lecturers were not encouraged to diversify their class activities and lead class discussions beyond the textbook scope. Although the system has been more open recently, providing the faculty with opportunities to design part of their own courses in line with the guidelines provided by the educational authority, the course contents are still found unsuitable for students $(\mathrm{H}$. T. Pham \& Ngo, 2008). Some lecturers have attempted to take risk, changing the contents of some parts or even the whole lesson to facilitate students' learning although they may never officially declare that. Consequently, students have been indicated to fail to obtain the program objectives (for more details, see Hoang, 2008; P. Nguyen, 2008; Thanh, 2008).

3. 2. 3. Persons

Vietnamese students have been traditionally associated with hard-working, and EFL students are not exceptions. In addition, EFL students are often said to be more open than those in other majors because of reading and discussing about the language whose culture is seen to be more relaxing than their own. In other words, they are not totally passive learners, and their identity change may have been promoted through learning activities. Many of them are supposed to be rooted in traditional rote learning methods, but that cannot always stop them from being active and striving for managing their learning processes more effectively. A student who went online only once or twice a week said that he read books and tried the practice tests in there. Meanwhile, some of his peers reported that they came to Google or other English learning sites for materials.

EFL students nowadays are also perceived to be active by their lecturers. Traditionally, teachers and lecturers alike expected their students to be quiet, listen attentively to the lecture during class time, and take part in drills when asked to; however, EFL lecturers nowadays agree to give their students more opportunities to deal with the language practically. Interactions between students have been more frequently seen in EFL classes. Group presentations and project work have also been employed here and there. More importantly, students are expected to invest time and energy apart from class, and lecturers attempt to shift away from their authoritarian role as indicated by an EFL lecturer who said:

"[... Outside of the class,] I communicate with students mainly via email and Facebook. Email is basically used for academic purposes such as sending files and assignments [...] It can also be served as an evidence of the transaction. Facebook is often used for spreading general information such as extra-curriculum activities, internship alerts, and scholarship news [...] thanks to its speeding propagation over the network."

Lecturer MP

These show that EFL students' out-of-class activities are also related to school if the lecturers attempt to maintain that connection.

\section{Discussion}

Coordinating attributes from the three dimensions of the framework effectively plays a significant role in promoting learner autonomy. In a situation of limited resource options at a school library as such, some students opt to internet resources while others have to end up with no reference materials or those that are not of their interest. In addition, if their teachers' class activities require work beyond the materials available to them, they may be suffered from frustration. Therefore, the lecturers should, for example, facilitate and students should be informed of attempts to collect and use materials collaboratively to resolve the problem. The lecturers should also adjust their lectures and course materials to help students take advantage of the resources currently available to them more efficiently. To implement these suggested plans properly, the lecturers will need to include 
students' voice and involvement in their action. However, if they choose not to modify their course requirements to suit the resources possibly available for students, the opportunity for monitoring learning processes, for example, becomes limited, and learner autonomy can be probably hindered.

While it is difficult for lecturers to negotiate with the educational authorities, negotiation with students is in lecturers' power. A student can become passive if he/she is framed in a locally so-called well-disciplined environment; however, he/she can become active and more involved in a learning process if he/she is adequately encouraged to participate in. It of course takes time for these explicitly dialogic negotiations and interactive activities to demonstrate effects in teaching and learning practices, especially when both students and teachers in the local context need to change some of their traditional learning routines and perspective on learning philosophy. Therefore, the lecturers should be able to determine their students' level of learner autonomy and have an appropriate course design to facilitate their engagement. Once students are able to modify their learning habits and move through their zone of proximal development (Lantolf \& Thorne, 2006), their learner autonomy capacity will be acquired and gradually enhanced.

To understand students' level of learner autonomy and provide suitable facilitations, the lectures need to take into account of the local socio-cultural characteristics. For example, people at these students' age in the local community are generally given limited choices in their daily life because they are believed not to be mature enough to control their behaviors. They are also expected to learn the knowledge from their teachers and take it as the only one correct source. Therefore, if too many options are suddenly given to them in a course, they may become confused and find it difficult to deal with. They may also find the course uninteresting because they are asked to look for and do with different knowledge resources while they are only familiar with learning from their teachers. As a result, they may not benefit much from the course.

Although learner autonomy is constructed, nurtured, and developed during one's interactions with the environment, it is a personal ability which is produced and performed by each individual in a certain context. One can exercise his/her learner autonomy at a high level in this context does not necessarily have to achieve the same level in other contexts. Similarly, the same situational facilitative attributes may have dissimilar effects on the development of learner autonomy of different members in that immediate context. Therefore, autonomy-promoting teaching practices need to provide learners wider opportunities for negotiations and choices to help them find their own learning path. This metacognitive process of interpreting and internalizing social attributes also needs to be nurtured and monitored properly.

\section{Conclusion}

Employing the socio-cultural theory lenses, the paper has discussed some advantages and disadvantages of learner autonomy promotion in Vietnamese EFL education and suggestions for its implementation. While it does not attempt to investigate a particular case, it addresses most of the typical issues associated with the facilitation of this construct in the local context. Further research needs to examine and document the local students' perceptions of learner autonomy attributes and their manifestation at both immediate and general level in the local context. That will help inform teachers, policy makers, and stakeholders of feasible and workable practices.

\section{References}

Asiaweek. (1999, 23 April). Asia's Best Universities 1999. Asiaweek, p. 3. Retrieved 10/10/2000, from http:/cgi.cnn.com/ASIANOW/asiaweek/universities/schools/index.html.

Bachman, J. (1964). Motivation in a task situation as a function of ability and control over task. Journal of Abnormal and Social Psychology, 69, 272-281.

Benson, P. (2001). Teaching and researching autonomy in language learning. London: Longman.

Benson, P. (2005). Autonomy and information technology in the educational discourse of the information age. In C. Davison (Ed.), Information technology and innovation in language education (pp. 173-191). Hong Kong: Hong Kong University Press.

Benson, P. (2006). Automony in language teaching and learning. State-of-the-art Article. Language Teaching, 40(1), 21-40.

Benson, P. (2009). Making sense of autonomy in language learning. In S. Toogood, R. Pemberton \& A. Barfield (Eds.), Maintaining control: Autonomy and language learning (pp. 13-26). Hong Kong: Hong Kong University Press.

Brandon, K. (2003). Best practice in guided individual learning in Australian ELICOS colleges. Paper presented at the Inaugural Independent Learning Association Conference. Retrieved 10-09-2008, from http://independentlearning.org/ILA/ila03/ila03_papers.htm. 
Breen, M. P., \& Mann, S. (1997). Shooting arrows at the sun: perspectives on a pedagogy for autonomy. In P. Benson \& P. Voller (Eds.), Autonomy and Independence in Language Learning (pp. 132-149). Harlow: Longman.

Cybermetrics Lab (2008). Regional and Global Ranking of South-East Asia Region. Madrid, Spain: CCHS-CSIC.

Dam, L. (1990). Learner autonomy in practice: An experiement in learning and teaching. In I. Gathercole (Ed.), Autonomy in language learning: papers from a conference held in Janaury 1990 (pp. 16-37). London: Centre for Information on Language Teaching \& Research.

Dickinson, L. (1987). Self-instruction in language learning. Cambridge [Cambridgeshire]; New York: Cambridge University Press.

Ellis, R. (1994). The study of second language acquisition. Oxford: Oxford University Press.

Gardner, R. \& MacIntyre, P. (1991). Motivational variables in second language acquisition. Studies in Second Language Acquisition, 13, 57-72.

H, A. (2007, 2 February). Benh luoi doc cua sinh vien [Students' laziness for reading]. Thanh Nien. Retrieved 01/09/2008, from http:/www.thanhnien.com.vn/2007/Pages/200705/180483.aspx.

HG, H. (2008, 24 November). Lo hong lon trong cong tac huong nghiep [A big gap in career orientation]. Tuoi Tre. Retrieved 24-11-2008, from http://www.tuoitre.com.vn/Tianyon/Index.aspx?ArticleID=289323\&ChannelID=13.

Hoang, T. (2008). Educational crisis: Reasons and solutions in globalization challenges Paper presented at the Comparative Education Conference 2008. Retrieved 10-07-2008, from $\mathrm{http}$ //ciecer.org/joomla/index.php?option=com_content\&task=view\&id=199\&Itemid=43.

Holec, H. (1981). Autonomy in foreign language learning. Oxford: Pergamon.

Holec, H. (1987). The learner as manager: Managing learning or managing to learn. In A. Wenden \& J. Rubin (Eds.), Learner strategies in language learning (pp. 145-157). Englewood Cliffs, New Jersey: Prentice-Hall Inc.

Horváth, I. (2005). The cognitive components of autonomous learning in postgraduate interpreter training. Paper presented at the 2nd Independent Learning Association Oceania Conference. Retrieved 10-10-2008, from http://independentlearning.org/ILA/ila05/ila05_papers.htm

Lamb, T. (2009). Controlling learning: Learners' voices and relationships between motivation and learner autonomy. In S. Toogood, R. Pemberton \& A. Barfield (Eds.), Maintaining control: Autonomy and language learning (pp. 67-86). Hong Kong: Hong Kong University Press.

Lantolf, J. P. (2000). Sociocultural theory and second language learning. Oxford: Oxford University Press.

Lantolf, J. P., \& Thorne, S. L. (2006). Sociocultural theory and the genesis of second language development. Oxford ; New York: Oxford University Press.

Lave, J., \& Wenger, E. (1991). Situated learning : legitimate peripheral participation. Cambridge [England]; New York: Cambridge University Press.

Le, H. P. (2008, 12-November). Su bao cap da troi buoc giao vien [The system of subsidies has tied up its teachers]. Tuoi Tre. $\quad$ Retrieved 13-11-2008, from http://www.tuoitre.com.vn/Tianyon/Index.aspx?ArticleID=287486\&ChannelID=13.

Little, D. (1990). Autonomy in Language Learning: Some theoretical and practical considerations. In I. Gathercole (Ed.), Autonomy in language learning: papers from a conference held in Janaury 1990 (pp. 106 p.). London: Centre for Information on Language Teaching \& Research.

Little, D. (1991). Learner autonomy 1: Definitions, issues, and problems. Dublin: Authentik.

Little, D. (2003). Learner autonomy and second/foreign language learning. Guide to Good Practice. Retrieved from http://www.llas.ac.uk/resources/gpg/1409.

Little, D. (2009). Learner autonomy, the European Language Porfolio and teacher development. In S. Toogood, R. Pemberton \& A. Barfield (Eds.), Maintaining control: Autonomy and language learning (pp. 147-173). Hong Kong: Hong Kong University Press.

Littlewood, W. (1996). "Autonomy": An anatomy and a framework. System, 24(4), 427-435. 
Littlewood, W. (1997). Self-access: why do want it and what can it do? In P. Benson \& P. Voller (Eds.), Autonomy and Independence in Language Learning (pp. 79-92). Harlow: Longman.

Luu, A. T. (2008, 4 November). Viet Nam dung thu 79 ve chi so phat trien giao duc [Vietnam's EDI ranks 79th]. Tuoi Tre. Retrieved 05-11-2008, from http://www.tuoitre.com.vn/Tianyon/Index.aspx?ArticleID=286274\&ChannelID=13.

Miller, L. (2009). Relective lesson planning: Promoting learner autonomy in the classroom. In R. Pemberton, S. Toogood \& A. Barfield (Eds.), Maintaining Control: Autonomy and Language Learning (pp. 109-124). Hong Kong: Hong Kong University Press.

Miller, L., Hopkins, M., \& Tsang, E. (2005). Self-access language learning in Hong Kong secondary schools. Paper presented at the 2nd Independent Learning Association Oceania Conference. Retrieved 10-10-2008, from http://independentlearning.org/ILA/ila05/ila05_papers.htm.

MOET (2008). Quyet dinh ve viec phe duyet de an 'Day va hoc ngoai ngu trong he thong giao duc quoc dan giai doan 2008-2020' [Decision on the approval of the project 'Teaching and learning foreign languages in the national education system in the period of 2008-2020']. Retrieved 10-11-2008. from http://moet.gov.vn/?page=6.4\&view $=708$.

Nguyen, D. T., \& Nguyen, P. T. (2008, 7 November). Doi moi phuong phap giang day: Lop qua dong: Lam sao doi moi? [Teaching methodology innovation: Big class size: How to innovate?]. Tuoi Tre. Retrieved 10-12-2008, from http://www.tuoitre.com.vn/Tianyon/Index.aspx?ArticleID=286734\&ChannelID=13.

Nguyen, P. (2008, 5 January). Chat luong giao duc dai hoc: Doi moi tu goc den ngon [Quality in higher education: An entire renovation]. Tuoi Tre. Retrieved 01/10/2008, from http:/www.tuoitre.com.vn/Tianyon/Index.aspx?ArticleID=237211\&ChannelID=13.

Nguyen, T. V. (2008, 20 January). Chat luong giao duc: Tu thay den tro [Educational quality: From teachers to students]. Nguoi Lao Dong. Retrieved 10-05-2008, from http://www.nld.com.vn/tintuc/giao-duc/213086.asp.

Nhom PV Giao Duc (2008, 13 November). Phuong phap giang day can phong phu hon [Teaching methods need to be more various]. Tuoi Tre. Retrieved 13-11-2008, from http://www.tuoitre.com.vn/Tianyon/Index.aspx?ArticleID=287604\&ChannelID=13.

Nunan, D. (1988). The learner-centred curriculum. Cambridge ; New York: Cambridge University Press.

Nunan, D. (1991). Language teaching methodology : a textbook for teachers. New York: Prentice-Hall.

Nunan, D. (1997). Designing and adapting materials to encourage learner autonomy. In P. Benson \& P. Voller (Eds.), Autonomy and Independence in Language Learning (pp. 192 - 203). Harlow: Longman.

Oxford, R. (2003). Toward a more systematic model of L2 learner autonomy. In D. Palfreyman \& R. Smith (Eds.), Learner autonomy across cultures: language education perspectives (pp. 75-91). New York: Palgrave Macmillan.

Pemberton, R., Toogood, S., \& Barfield, A. (Eds.). (2009). Maintaining Control: Autonomy and Language Learning. Hong Kong: Hong Kong University Press.

Pennycook, A. (1997). Cultural alternatives and autonomy. In P. Benson \& P. Voller (Eds.), Autonomy and independence in language learning (pp. 18-34). London: Longman.

Pham, H. H. (1999). The key socio-cultural factors that work against success in tertiary English language training programs in Vietnam. Paper presented at the The fourth International Conference on language and Development. Retrieved 5-10-2008, from http://www.languages.ait.ac.th/hanoi_proceedings/hiep.html.

Pham, H. T., \& Ngo, A. D. (2008). Phat trien nguon nhan luc cong nghiep o Viet Nam trong giai doan moi cua cong nghiep hoa [Human development for Vietnam industry in the period of industrialization]. Retrieved from http://www.vdf.org.vn/Doc/2008/VDFConf_WIPHoangVie.pdf.

Purdie, N., Hattie, J., \& Douglas, G. (1996). Student conceptions of learning and their use of self-regulated learning strategies: A cross-cultural comparison. Journal of Educational Psychology, 88(1), 87-100.

Raz, J. (1986). The morality of freedom. Oxford: Oxford University Press.

Riley, P., \& Zoppis, C. (1985). The sound and video library. In P. Riley (Ed.), Discourse and Learning (pp. 114-131). London: Longman.

Rivers, W. P. (2001). Autonomy at All Costs: An Ethnography of Metacognitive Self-Assessment and Self-Management among Experienced Language Learners. The Modern Language Journal, 85(2), 279-290. 
Schunk, D., \& Zimmerman, B. J. (1994). Self-regulation of learning and performance: Issues and educational applications. Hillsdale, NJ: Erlbaum.

Sinclair, B. (2009). The teacher as learner: Developing autonomy in an interactive learning environment. In R. Pemberton, S. Toogood \& A. Barfield (Eds.), Maintaining Control: Autonomy and Language Learning (pp. 175-198). Hong Kong: Hong Kong University Press.

Smith, R. (2003). Postcript: Implications for language education. In D. Palfreyman \& R. Smith (Eds.), Learner autonomy across cultures: language education perspectives (pp. 254-260). New York: Palgrave Macmillan.

Smith, R., \& Ushioda, E. (2009a). 'Autonomy': under whose control? In R. Pemberton, S. Toogood \& A. Barfield (Eds.), Maintaining Control: Autonomy and Language Learning (pp. 241-253). Hong Kong: Hong Kong University Press.

Tarone, E., \& Yule, G. (1989). Focus on the language learner. Oxford: Oxford University Press.

Thanh, H. (2008, 6 December). Giang day tieng Anh trong cac truong DH: kem vi thieu chuan [Teaching English in Universities: Ineffective Due to Lack of Standard]. Tuoi Tre. Retrieved 10/12/2008, from http://www.tuoitre.com.vn/Tianyon/Index.aspx?ArticleID=291254\&ChannelID=13

Toohey, K. (2007). Conclusion: Autonomy/Agency through socio-cultural lenses. In A. Barfield \& S. H. Brown (Eds.), Reconstructing autonomy in language education: inquiry and innovation (pp. 231-242). Basingstoke: Palgrave Macmillan.

Tran, T. D. (1996, 12 May). So phan cac sinh ngu thoi hien dai [The fate of foreign languages in modern time]. Giao Duc Thoi Dai, p. 8,

Waterhouse, P. (1990). Supported self-study across the curriculum. In I. Gathercole (Ed.), Autonomy in language learning: papers from a conference held in Janaury 1990 (pp. 4-6). London: Centre for Information on Language Teaching \& Research.

Wenger, E. (1999). Communities of practice: learning, meaning, and identity. Cambridge, MA: Cambridge University Press.

Wenger, E., McDermott, R. A., \& Snyder, W. (2002). Cultivating communities of practice : a guide to managing knowledge. Boston: Harvard Business School Press.

World Bank (2006). Education in Vietnam: Development history, challenges and solutions. Washington, DC.

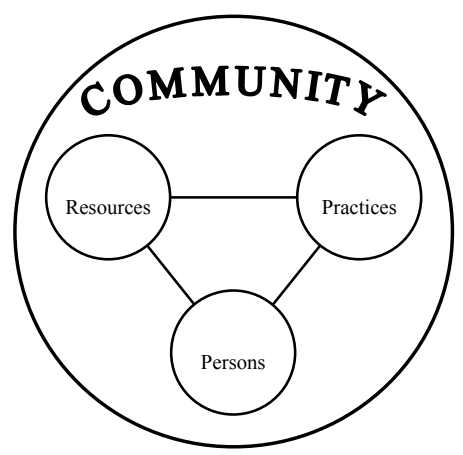

Figure 1. Socio-cultural perspective on the capacity of learner autonomy (adapted from Toohey, 2007, p. 233) 